\title{
Uncovering the hidden diversity of Mississippian crinoids (Crinoidea, Echinodermata) from Poland
}

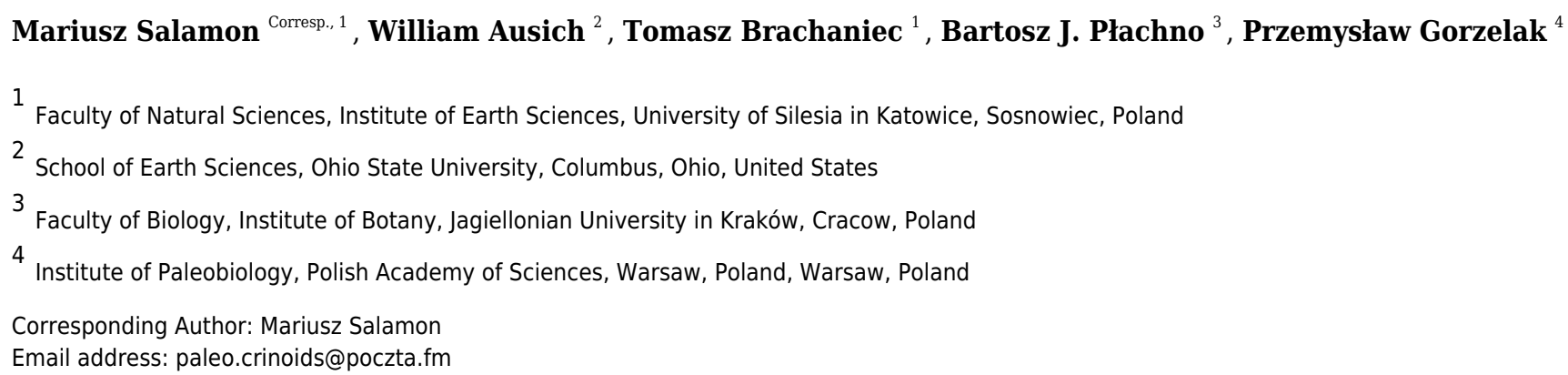

Partial crinoid crowns and aboral cups are reported from the Mississippian of Poland for the first time. Most specimens are partially disarticulated or isolated plates, which prevent identification to genus and species, but regardless these remains indicate a rich diversity of Mississippian crinoids in Poland during the Mississippian, especially during the late Viséan. Lanecrinus? sp. is described from the late Tournaisian of the Dębnik Anticline region. A high crinoid biodiversity occurred during late Viséan of the Holy Cross Mountains, including the camerate crinoids Gilbertsocrinus? sp., Platycrinitidae Indeterminate; one flexible crinoid; and numerous eucladid crinoids, including Cyathocrinites mammillaris (Phillips), three taxa represented by partial cups left in open nomenclature, and numerous additional taxa known only from isolated radial plates, brachial plates, and columnals. To date, the youngest occurrence of Gilbertsocrinus was the early Viséan of the United States, thus the present finding in upper Viséan extends this genus range. Furthermore, the occurrence of Lanecrinus? sp. expands the Western European range of this genus into the Tournaisian. A single partially disarticulated crown, Crinoidea Indeterminate B, is described from the Serpukhovian of the Upper Silesian Coal Basin. In addition, several echinoid test plates and spines are also reported. 
1 Uncovering the hidden diversity of Mississippian crinoids (Crinoidea, Echinodermata)

2 from Poland

3

4 Mariusz A. Salamon ${ }^{1}$,William I. Ausich², Tomasz Brachaniec ${ }^{1}$, Bartosz J. Płachno ${ }^{3}$ \&

5 Przemysław Gorzelak ${ }^{4}$

6

$7{ }^{1}$ University of Silesia in Katowice, Faculty of Natural Sciences, Institute of Earth Sciences,

8 Będzińska Street 60, 41-200 Sosnowiec, Poland, e-mail: paleo.crinoids@poczta.fm

$9{ }^{2}$ Ohio State University, School of Earth Sciences, 125 South Oval Mall, Columbus, Ohio, United 10 States

${ }^{3}$ Jagiellonian University in Kraków, Faculty of Biology, Institute of Botany, Gronostajowa Street 9, 30-387 Cracow, Poland

${ }^{4}$ Institute of Paleobiology, Polish Academy of Sciences, Twarda 51/55, 00-818 Warsaw, Poland

Corresponding Author:

Mariusz A. Salamon ${ }^{1}$

${ }^{1}$ University of Silesia in Katowice, Faculty of Natural Sciences, Institute of Earth Sciences, Będzińska Street 60, 41-200 Sosnowiec, Poland

e-mail: paleo.crinoids@poczta.fm

\section{Abstract}

Partial crinoid crowns and aboral cups are reported from the Mississippian of Poland for the first time. Most specimens are partially disarticulated or isolated plates, which prevent identification to genus and species, but regardless these remains indicate a rich diversity of Mississippian crinoids in Poland during the Mississippian, especially during the late Viséan. Lanecrinus? sp. is described from the late Tournaisian of the Dębnik Anticline region. A high crinoid biodiversity occurred during late Viséan of the Holy Cross Mountains, including the camerate crinoids Gilbertsocrinus? sp., Platycrinitidae Indeterminate; one flexible crinoid; and numerous eucladid crinoids, including Cyathocrinites mammillaris (Phillips), three taxa represented by partial cups left in open nomenclature, and numerous additional taxa known only from isolated radial plates, brachial plates, and columnals. To date, the youngest occurrence of Gilbertsocrinus was the early Viséan of the United States, thus the present finding in upper Viséan extends this genus range. Furthermore, the occurrence of Lanecrinus? sp. expands the Western European range of this genus into the Tournaisian. A single partially disarticulated crown, Crinoidea Indeterminate B, is described from the Serpukhovian of the Upper Silesian Coal Basin. In addition, several echinoid test plates and spines are also reported. 


\section{Introduction}

Complete aboral cups and crowns of crinoids have not been described previously from Mississippian sediments of Poland. Based on isolated remains Geinitz (1846), Roemer (1870), Schmidt (1930), and Korejwo and Teller (1968a, b), identified Cyathocrinites, Platycrinites, and Poteriocrinites or Ulocrinus. Głuchowski (1980a, b, 1981a, b, 1982, 1986, 2001) distinguished dozens of columnal taxa from Carboniferous sediments, mainly in southern Poland, using the parataxonomic columnal taxonomy of Moore \& Jeffords (1968). Based on columnal taxonomy, Głuchowski (1986) recognized a change in Polish columnal faunas after the Late Devonian. He documented the first crinoid columnal occurrences in Poland from the middle Tourniasian. They were represented by an assemblage with low biodiversity and dominated by isolated remains of Cyclocaudiculus (col.) gracilis Głuchowski. Cyclocaudicus (col.) gracilis remained the main component of the late Tournaisian of western Pomerania (northern Poland). Głuchowski (2001) stressed that the assemblage in the Tournaisian of the Holy Cross Mountains was diverse, being represented by 12 species of which 11 were new. However, as noted all taxa described by Głuchowski (1986) were created based solely on isolated ossicles (no whole or partly preserved cups were recorded). Głuchowski (1986) concluded that this assemblage was endemic and not similar to other late Tournaisian crinoids noted elsewhere in Poland. The most common crinoid taxa in the late Tournaisian of the Upper Silesian Coal Basin were Ampholenium (col.) apolegma Moore \& Jeffords, Flucticharax (col.) undatus Moore and Jeffords, and Rhysocamax (col.) cristata Moore and Jeffords. A high crinoid biodiversity was also noted for the Viséan. The most common Viséan columnals were Preptopremnum (col.) rugosum Moore \& Jeffords and Cyclocrista (col.) lineolata Moore \& Jeffords (Głuchowski, 2001). Crinoid remains were also reported from the Viséan of the Lagów and Kielce Through (southern Poland, Holy Cross Mountains); the Viséan and Namurian of the Upper Silesian Coal Basin; the Viséan, Namurian, and Westphalian of the Lublin Coal Basin (eastern Poland); and from Sudetes (Żakowa, 1956a, b, 1962; Żakowa \& Malec, 1992; for a summary see table 14 in Głuchowski, 2001).

Complete or almost complete Mississippian aboral cups and partial crowns associated with numerous completely disarticulated remains are reported here for the first time from three different exposures in southern Poland (Dębnik Anticline, Holy Cross Mountains, and Upper Silesian Coal Basin).

\section{Stratigraphical setting}

\section{Dębnik Anticline}

The active Czatkowice Quarry is located near Krzeszowice in the Dębnik Anticline with coordinates $50^{\circ} 09^{\prime} 32.0^{\prime \prime} \mathrm{N} 19^{\circ} 38^{\prime} 17.6^{\prime \prime} \mathrm{E}$ (Fig. 1D). It is placed along the eastern edge of the postHercynian structure, the so-called Sławków Graben. This anticline is filled by Devonian (Givetian-Fammenian) sediments, mainly limestones and dolomites. This sequence is overlain by upper Tournaisian and middle Viséan limestones toward the western part of the anticline (Paszkowski, 2009; Salata, 2013). To the west of the quarry, the Palaeozoic deposits are followed by Triassic and Jurassic sediments. Moving eastward from the quarry, Cambrian to Mississippian strata are covered by Jurassic rocks (e.g., Salata, 2013).

The described single crinoid specimen was collected in the early 2000s in a brown limestone layer $\sim 5 \mathrm{~cm}$ thick. This limestone was a part of larger carbonate sequence with a thickness of 
82

83

84

85

86

87

88

89

90

91

92

93

94

95

96

97

98

99

100

101

102

103

104

105

106

107

108

109

110

111

112

113

114

115

116

117

118

119

120

121

122

123

124

125

126

several metres. It belongs to the Mazurowe Doły Formation, which is part of the so-called Rudawa Group (Fig. 2A). The latter formation is a shallowing-upward succession of hummocky cross-stratified and oolitic grainstone that was deposited in a storm-dominated ramp (e.g., Paszkowski et al., 2008). The age of the Mazurowe Doły Formation is late Tournaisian based on co-occurring foraminifera and rugose corals (Poty et al., 2007). Other fossils of this formation are thin-shelled brachiopods, solitary corals, bryozoans, unidentifiable isolated crinoid columnals, gastropods, bivalves, and cephalopods (Thuy et al., 2015 and literature cited therein). The latter authors recorded an articulated ophiuroid specimen of Aganaster jagiellonicus in this formation. According to Paszkowski et al. (2008), the Mazurowe Doły Formation was deposited in a shallow, strongly turbulent subtidal zone with paleo-depths above storm wave base.

\section{Holy Cross Mountains}

The active quarry Ostrówka, situated near Gałęzice village, is located in the Kielce Zone of the Holy Cross Mountains with coordinates 5050'26.5"N 20²4'03.7"E (Fig. 1B). In the Gałęzice area the lithological sequence starts with shallow-water platform carbonates of Frasnian age, which are mainly fine-grained limestones (Fig. 2B). This lithotype is characteristic of Devonian shallow-water environments and is typically interpreted as having been deposited in restricted lagoons between stromatoporoid-coral mounds (Larsen et al., 1988). Above the Frasnian deposits is a Famennian pelagic cephalopod limestone. It is a bioclastic wackestone rich in comminuted skeletal debris, containing trilobites, crinoids, ostracodes, and goniatites. The limestone was deposited below the photic zone and storm wave-base. The high content of conodonts suggests a relatively low rate of sedimentation (Bełka et al., 1996). Above the Famennian are pelagic carbonates of Tournaisian age. These deposits are mainly limestone breccia and mudstones. Breccia with broken crinoid (pluri)columnals represent the infill of neptunian dykes within the Frasnian host rocks (Bełka et al., 1996). Tournaisian mudstones are mostly yellow with rare fossils. This micritic lithology indicates a deep marine, pelagic depositional environment (Bełka et al., 1996). Overlying Tournaisian deposits are radiolarian shales with cherts of the lowermiddle Viséan Zaręby Beds. Above, the middle-upper Viséan are sediments representing facies equivalent to the Lechówek Beds. This sequence begins with breccias containing clasts of the Frasnian-Viséan rocks, crinoidal limestone, and shales with intercalations of siltstone and sandstone. Most of the crinoids described here $(\sim 99 \%)$ are from these late Viséan crinoidal limestones. These sediments are interpreted as gravity flow sediments moved from a shallow platform to a deep basin setting. The age of the Viséan limestones was confirmed by the presence of a diverse foraminiferal fauna dominated by representatives of the genera Endothyra, Howchinia, Valvulinella, Archaediscus, and Tetrataxis (Bełka et al., 1996).

The upper Viséan deposits studied were exposed on the slope in the southeastern part of Ostrówka quarry in 2019. The strata studied was a package of poorly-sorted, coarse-grained crinoidal packstone to rudstone layers, each 30-120 cm thick (Fig. 3J). All these layers contain an extremely abundant and diverse shallow-water benthic fauna: echinoderms, brachiopods, and solitary and colonial corals. These deposits represent material that was transported from an adjacent carbonate platform and deposited in a deeper, lower-slope environment that was part of a submarine, deep-water channelized slope fan (Bełka \& Skompski, 1988). This has been interpreted as a mixture of faunal elements originating from different ecological niches based on the anatomy of the carbonate lenses, grain-supported texture, chaotic clast arrangement, preferred orientation of elongated bioclasts (rugose corals, crinoid stems), and the presence of

Peer) reviewing PDF | (2020:10:53626:1:2:NEW 24 Nov 2020) 
127

128

129

130

131

132

133

134

135

136

137

138

139

140

141

142

143

144

145

146

147

148

149

150

151

152

153

154

155

156

157

158

159

160

161

162

163

164

165

166

167

168

169

170

reworked fragments from the substrate (Bełka \& Skompski, 1988; Bełka et al., 1996). According to Bełka \& Skompski (1988), the transport direction appears to be toward the north. So, the source area from which the clast material of the investigated debrite was derived was located south of the Gałęzice area, but the geographical extent cannot be precisely outlined.

\section{Upper Silesian Coal Basin}

The historical outcrop in Gołonóg (coordinates 50¹9'52.7"N 19¹5'33.3"E) is located in northeastern part of the Upper Silesian Coal Basin (Fig. 1C). Here the Pennsylvanian sediments overlie Mississippian mudstones and sandstones of the Culm facies in the western part and Mississippian limestone facies in the eastern part. Mississippian deposits (Serpukhovian; Namurian regional stage) start with the so-called Paralic Series that are represented by mudstones, sandstones and coal seams (Fig. 2C). Above is the so-called Limnic Series (Serpukhovian and Bashkirian) with the Upper Silesian Sandstone Series (Serpukhovian), and the Mudstone Series (Bashkirian). These sediments are represented by mudstones interbedded with sandstones and coal seams. At the top of Carboniferous sediments, mudstones and sandstones of the Kraków Sandstone Series (uppermost Westphalian) are present. These sediments occur only in the eastern part of Upper Silesian Coal Basin (e.g., Krawczyński, 2013). The described single specimen was found in 2019 within the Gołonóg Sandstones Serpukhovian; early Namurian A age. The Serpukhovian age was determined by Doktorowicz-Hrebnicki (1935), Czarniecki (1959), and Kotas (1972). These sediments belong to Malinowice Beds partly belonging to Marine Diastrophic Series and Paralic Series. Gołonóg Sandstones are located at the boundary of these two series. At present, only a $50 \mathrm{~cm}$ thick set of sandstone interbedded with mudstone is exposed in the trail-cut between city districts Tworzeń and Laski of Dąbrowa Górnicza. Within these sediments, external and internal molds of corals, bivalves, gastropods, trilobites, and brachiopods are common (Weigner, 1938; Krawczyński, 2013 and literature cited therein). Salamon (1998) also mentioned disarticulated crinoid columnals and pluricolumnals from Gołonóg.

Figure 1 and 2 around here

\section{Materials and methods}

The studied material from Czatkowice Quarry (Dębnik Anticline) was collected by Prof. Edward Głuchowski during the early 2000s (two specimens). A single specimen from the Gołonóg sandstones (Upper Silesian Coal Basin) was collected in 2019. The studied material from Gałęzice in the Holy Cross Mountains was collected during the autumn of 2019 and winter of 2020. More than 10,000 columnals and pluricolumnals, a few hundred disarticulated ossicles from aboral cups, arms, columns; and six partially complete crowns/aboral cups were collected in the latter area. The first step consisted of examination of slab surfaces in the field. At this stage, numerous crinoid remains were identified. The next step consisted of soaking seven carbonate samples with Glauber's salt weighing each from 5 to $7 \mathrm{~kg}$. They were then successively boiled and frozen; depending on hardness of the rock sample, from 1 to as many as 3 times. The residues were finally washed with running tap water and sieved on a sieve column (1.0, 0.315 and $0.1 \mathrm{~mm}$ mesh size). The final step consisted of drying the respective washed residues at $160^{\circ} \mathrm{C}$. Residue was hand-picked from each macerated sample for microscopic study. 
171 Some specimens were cleaned with hot hydrogen peroxide and then rinsed under running hot tap 172 water.

173 All larger crinoids were photographed by a Nikon D7100 digital camera, whereas smaller forms 174 by scanning microscope (SEM), a Philips XL-20 at the Institute of Paleobiology of the Polish 175 Academy of Sciences in Warsaw.

176 The crinoid collection from is housed at the University of Silesia in Katowice, Faculty of Natural 177 Sciences, Institute of Earth Sciences, Poland, under catalogue number: GIUS 5-3695, 5-543.

178

179

180

181

182

183

184

185

186

187

188

189

190

191

192

193

194

195

196

197

198

199

200

201

202

203

204

205

206

207

208

209

210

211

\section{Results}

Systematic paleontology

The classification used herein follows the phylogeny-based revision of crinoid higher taxa by Ausich et al. (2015), Wright (2017a, 2017b), Wright et al. (2017), and Cole (2017, 2018). Morphological terminology follows Ubaghs (1978a), with modifications from Webster (1974, for nodal and internodal terminology), Webster and Maples (2008, fig. 10.2; for brachial plate terminology), Ausich et al. (2015), and Ausich et al. (2020). All measurements are in mm, with * indicating an incomplete or crushed specimen. Abbreviations for measurements are the following: $\mathrm{ACH}$, aboral cup height; $\mathrm{ACW}$, aboral cup width; $\mathrm{AH}$, arm height; $\mathrm{BH}$, basal plate height; $\mathrm{BW}$, basal plate width; $\mathrm{CH}$, column height; $\mathrm{CoH}$, columnal height; CoW, columnal width; ComaxW, columnal maximum width; CominW, columnal minimum width; $\mathrm{CrH}$, crown height, IH, infrabasal plate height; $\mathrm{PbrH}$, primibrachial height; PbrW, primibrachial width; $\mathrm{PCoH}$, pluricolumnal height, RH, radial plate height; RW, radial plate width; RFW, radial facet width; RmaxW, radial plate maximum width, SBrH, secundibrachial height; SBrW, secundibrachial width.

\section{Class Crinoidea Miller, 1821}

Subclass Camerata Wachsmuth \& Springer, 1885

Infraclass Eucamerata Cole, 2017

Order Diplobathrida Moore \& Laudon, 1943

Family Rhodocrinitidae Roemer, 1855 (in Bronn \& Roemer, 1851-1856)

Genus Gilbertsocrinus Phillips, 1836

Type species: Gilberstocrinus calcaratus Phillips, 1836.

Gilbertsocrinus? sp.

Fig. 4A-C

Material: GIUS 5-3695/Ostrówka 4-6.

Discussion: Gilberstocrinus (sensu Ubaghs 1978b) is among the youngest known genera of diplobathrid camerates. It is recognized from Middle Devonian through middle Mississippian (Viséan) strata from Belgium, Canada, China, Ireland, the United Kingdom and the United 
212 States. Several morphological aspects of the arms, tegmen, and column of Gilbertsocrinus are 213 unique, which pose interesting questions about their palaeoecology (Van Sant \& Lane, 1964; 214 Riddle et al., 1988; Hess et al., 2001; and Hollis \& Ausich, 2008). Columnals from the late 215 Viséan of southern Poland have a morphology that aligns them with Gilbertsocrinus.

216

217

218

219

220

221

222

223

224

225

226

227

228

229

230

231

232

233

234

235

236

237

238

239

240

241

242

243

244

245

246

247

248

249

250

251

252

253

The column construction and columnal facet morphology combine to make Gilbertsocrinus among the most flexible columns known (Lane, 1963; Riddle et al., 1988; Hollis \& Ausich, 2008). One wide and high columnal alternates with one narrower and lower columnal along the column of Gilbertsocrinus. From the center outward on larger columnals, a columnal facet has a narrow central lumen surrounded by a narrow perilumen with a crenularium. Next is a very wide areola that is surround near the outer periphery by another crenularium. Finally, a narrow epifacet is present around the outer margin of the columnal (Riddle et al., 1988). The narrower, shorter columnals have the same morphology, except the epifacet is absent. When the column was in an erect life position, the only contact between adjoining columnals was around the narrow perilumen near the center of the columnals (Riddle et al., 1988).

Some upper Viséan columnals from Poland resemble this morphology and are assigned to Gilbertsocrinus? sp. (Fig. 4A-C). Examples are somewhat worn, which obscures details of the morphology. Also, this occurrence is a range extension for Gilbertsocrinus. Previously, the youngest occurrence of Gilbertsocrinus was the early Viséan of the United States. This occurrence questionably extends this genus range to the upper Viséan.

Measurements: GIUS 5-3695/Ostrówka 4: CoW, 3.1; PCoH, 0.5 (3 columnals). GIUS 53695/Ostrówka 5: CoW, 2.8; PCoH, 0.4.

Range: Lechówek Beds (late Viséan); Ostrówka Quarry near Gałęzice, Holy Cross Mountains, Poland.

Order Monobathrida Moore \& Laudon, 1943

Family Platycrinitidae Austin \& Austin, 1842

Platycrinitidae Indeterminate

Figs 4H, I

Material: GIUS 5-3695/Ostrówka 7, 8.

Discussion: Ausich \& Kammer (2009) recognized that morphological characters that defined platycrinitid genera in Western Europe were not uniformly applied worldwide. Accordingly, Ausich \& Kammer (2009) refined genus concepts for the Platycrinitidae, which included a few new genera and many generic reassignments. They assigned many species to Platycrinites sensu lato to refer to species that lack preservation of genus-diagnostic characters.

When first described, the most unique character for Platycrinites Miller, 1821 was elliptical columns with an articular ridge running across the long diameter of the elliptical columnal. The ridges on the upper and lower facet of a single columnal are offset, which results in the characteristic helical spiral of the platycrinitid column (Wachsmuth \& Springer, 1897; Van Sant \& Lane, 1964). Historically, middle to late Palaeozoic elliptical columnals have been identified as Platycrinites; however, following generic revisions of Ausich \& Kammer (2009), this 
254

255

256

257

258

259

260

261

262

263

264

265

266

267

268

269

270

271

272

273

274

275

276

277

278

279

280

281

282

283

284

285

286

287

288

289

290

291

292

293

294

295

columnal morphology is recognized as characteristic for the Platycrinitidae in general rather than as Platycrinites.

Only three platycrinitid genera have ranges that include the late Viséan: Eucladocrinus, Platycrinites, and Pleurocrinus. However, only Platycrinites s.l. and Pleurocrinus have described species from the late Viséan of Western Europe, including Platycrinites s.l. conglobatus (Wright, 1937), Platycrinites s.l. crassiconus (Wright, 1937), Platycrinities s.l. invertielensis (Wright, 1942), Platycrinites s.l. murkirkensis (Wright, 1956b), Platycrinites s.l. spiniger (Wright, 1937), Pleurocrinus balladoolensis (Wright, 1938) and Pleurocrinus vesiculosus (M’Coy, 1849) (Ausich \& Kammer, 2006; Kammer \& Ausich, 2007).

A few platycrinitid columnals are present from the upper Viséan of Poland (Fig. 4H, I). Overall, these columnals are relatively small and the height: maximum width ratio (0.6) is relatively high. GIUS 5-3695/Ostrówka 7 has a concave latus, but nodes are present at mid-height around the latus of GIUS 5-3695/Ostrówka 8. It is not possible to confidently assign these specimens to a genus, so they are referred to Platycrinitidae Indeterminate (Fig. 4H, I).

Measurements: GIUS 5-3695/Ostrówka 7: CoH, 1.8; CoMaxW, 3.0; CoMinW, 2.0.

Range: Lechówek Beds (late Viséan); Ostrówka Quarry near Gałęzice, Holy Cross Mountains, Poland.

Subclass Pentacrinoidea Wright, 2017

Infraclass Inadunata Wachsmuth \& Springer, 1885

Parvclass Cladida Moore \& Laudon, 1943

Cladida Indeterminate A

Fig. 3A, B

Material: GIUS 5-3695/Ostrówka 2.

Description: Incomplete crown from the radial plates to $\sim$ secundibrachial 12 . Crown medium in size, plate sculpturing smooth. Aboral cup shape, infrabasal plates, basal plates, and posterior interray plating unknown. Radial plates $\sim 1.3$ times wider than high; radial facets angustary ( $44 \%$ radial plate width). Second primibrachial axillary (Fig. 3A). Secundibrachial width expanded slightly proximally and distally resulting in a broadly concave outline aborally and along the sides of brachials (Fig. 3B). Column unknown.

Discussion: The wide radial facets with angustary radial facets, two primibrachials, 10 total arms, and no apparent ramules or pinnules do not correspond with another Mississippian crinoid. The radial plates are similar to those of Pelecocrinus magnus (Wright, 1937); however, $P$. magnus is only known from isolated aboral cup plates, and other species of Pelecocrinus are distinct from GIUS 5-3695/Ostrówka 2. Until a specimen is collected with a complete aboral cup, including the CD interray, it is not possible to designate GIUS 5-3695/Ostrówka 2 as either an unusual new species of an existing genus or a new genus. Thus, this taxon is left in open nomenclature at this time.

Measurements: GIUS 5-3695/Ostrówka 2: CrH, 23.0*; RH, 2.0; RW, 2.6; PbrH, 1.0; PbrW, 1.4; $\mathrm{SbrH}, 1.5 ; \mathrm{SbrW}, 1.6$; AH, 20.0*. 
296

297

298

299

300

301

302

303

304

305

306

307

308

309

310

311

312

313

314

315

316

317

318

319

320

321

322

323

324

325

326

327

328

329

330

331

332

333

334

335

336

337

338

339

340

Range: Lechówek Beds (late Viséan); Ostrówka Quarry near Gałęzice, Holy Cross Mountains, Poland.

Cladida Indeterminate B

Fig. 3C, D

Material: GIUS 5-3695/Ostrówka 3.

Description: GIUS 5-3695/Ostrówka 3 is a set of five articulated aboral cup plates: two radial plates, two basal plates and one infrabasal plate (Fig. 3C). The aboral cup shape is either medium or high cone shaped (as preserved). Percentages of plate circlets comprising the aboral cup are $\sim 13 \%$ infrabasal circlet, $\sim 4 \%$ basal circlet, and $\sim 40 \%$ radial circlet. Radial facets are plenary with a straight articular ridge across the entire facet, an aboral ligament fossae and one or two adoral fossae on each side of the adoral groove (Fig. 3D).

GIUS 5-3695/Ostrówka 3 clearly belongs in the articuliformes clade; but without knowledge of the arms and posterior interray plating, this crinoid must remain in open nomenclature.

Measurements: GIUS 5-3695/Ostrówka 3: RH, 4.6; RW, 6.3.

Range: Lechówek Beds (late Viséan); Ostrówka Quarry near Gałęzice, Holy Cross Mountains, Poland.

Superorder Flexibilia Zittel, 1895

Flexibilia Indeterminate

Fig. 5A-E, G, H

Material: GIUS 5-3695/Ostrówka 12-19.

Remarks: Many flexible crinoids have a patelloid process on their brachials, which is a unique character for the flexible clade (Van Sant \& Lane, 1964; Ubaghs, 1978a). The patelloid process is a short, thin extension from the central part of the proximal outer portion of the brachial plate that fits into a corresponding notch on the distal portion of the subjacent brachial plate. In some genera, a patelloid process is also present on the radial plate-first primibrachial articulation. One radial plate with a notch for a patelloid process (GIUS 5-3695/Ostrówka 12, Fig. 5A, B) and several brachial plates with a patelloid process are present in washed residues from the late Viséan Lechówek Beds (GIUS 5-3695/Ostrówka 12-19). The articular facets of brachials are unifascial (Fig. 5C-E) with a narrow crenularium around the margin of the facet and would be termed a synostosis (Fig. 5C). GIUS 5-3695/Ostrówka 14 is an axillary brachial (Fig. 5G, H).

Although diminished in biodiversity by the late Viséan, several genera of flexible crinoids were present during this time. Unfortunately, no genus- or species-level traits are present on these radial and brachial plates, and their identification must be left in open nomenclature.

Measurements: GIUS 5-3695/Ostrówka 12 (radial plate): RH, 1.7; RW, 3.4. GIUS 53695/Ostrówka 14 (nonaxillary brachial): BrH, 2.6; BrW, 4.7.GIUS 5-3695/Ostrówka 15 (axillary brachial): $\mathrm{BrH}, 2.8$; BrW, 4.5 .

Range: Lechówek Beds (late Viséan); Ostrówka Quarry near Gałęzice, Holy Cross Mountains, Poland.

Magnorder Eucladida Wright, 2017

Peer] reviewing PDF | (2020:10:53626:1:2:NEW 24 Nov 2020) 
341 Superorder Cyathoformes Wright et al., 2017

342 Family Cyathocrinitidae Bassler, 1938

343 Genus Cyathocrinites Miller, 1821

344

Type species: Cyathocrinites planus Miller, 1821

346

347

Cyathocrinites mammillaris (Phillips, 1836)

348

Fig. 3F, G

Material: GIUS 5-3695/Ostrówka 1.

351

352

353

354

355

356

357

358

359

360

361

362

363

364

365

366

367

368

369

370

371

372

373

374

375

376

377

378

Description: Aboral cup medium globe cone shape, height to width ratio 0.75; plates convex, smooth. Infrabasal plates presumably five, infrabasal circlet visible in lateral view, $\sim 22 \%$ of the aboral cup height. Basal plates presumably five, hexagonal, convex, smaller that radial plates, $\sim 32 \%$ of the aboral cup height. Radial plates higher than wide, $\sim 46 \%$ of the aboral cup height (Fig. 3F). Radial facets subcircular, strongly declivate, $\sim 72$ percent of distal radial plate width, occupy more than half of the radial facet area; radial facet morphology smooth (Fig. 3F, G).

CD interray, arms, and column unknown.

Discussion: The posterior interray on GIUS 5-3695/Ostrówka 1 is not known; but in other aspects, this specimen conforms with the morphology of Cyathocrinites mammillaris. Cyathocrinites mammillaris is a widespread species in Western Europe, having been reported previously from the Tournaisian and lower Viséan of Belgium, Germany, Spain, and the United Kingdom (see Ausich \& Kammer, 2006). The isolated radial plates, GIUS 5-3695/Ostrówka 10, 11, may also belong to Cyathocrinites.

Measurements: GIUS 5-3695/Ostrówka 1: ACH, 15.0; ACW, 20.0; IH, 4.0; BH, 6.0; BW, 8.0; RH, 8.5; RW, 8.5.

Range: Lechówek Beds (late Viséan); Ostrówka Quarry near Gałęzice, Holy Cross Mountains, Poland.

Superorder Articuliformes Wright et al., 2017

Family Decadocrinidae Bather, 1890

Genus Lanecrinus Kammer \& Ausich, 1993

Type species: Scaphiocrinus depressus Meek \& Worthen, 1870

Lanecrinus? sp.

Fig. $3 \mathrm{H}$

Material: GIUS 5-543. 
379 Description: Crown very small; smooth plate sculpturing, as known. Shape of aboral cup,

380

381

382

383

384

385

386

387

388

389

390

391

392

393

394

395

396

397

398

399

400

401

402

403

404

405

406

407

408

409

410

411

412

413

414

415

416

417

418

419

420

421

422

423

424 including posterior interray, not known. Radial facets plenary.

Ten total arms, pinnulate; single isotomous division on first primibrachial. Primibrachials very high, height to width ratio (2.0-3.0). Secundibrachials high, uniserial, moderately cuneate, very high, height to width ratio (2.8-3.0); at many as seven secundibrachials preserved in half-rays. Pinnules articulated to high side of cuneate secundibrachials, long, stout.

Column circular. Proximal portion of proxistele with one wide nodal with a convex latus alternating with one internodal. In distal portion of proxistele, additional cycles of internodals are inserted.

Discussion: GIUS 5-543 is a ten-armed eucladid with a poorly preserved aboral cup; one elongate primibrachial in each ray; elongate, cuneate secundibrachials; prominent pinnules; and a distinctive proximal column. Three aspects of this specimen make it difficult to identify with certainty, including the absence of the CD interray, unknown nature of the aboral cup shape, and the possibility that the small overall size and high brachial plates are indicative of a juvenile specimen.

Known characters of GIUS 5-543 align with Lanecrinus Kammer \& Ausich, 1993. The high brachial plates and robust pinnules (Fig. 3H) are similar to two Western European species of Lanecrinus, L. fifensis (Wright, 1934), Viséan, United Kingdom; and L. trymensis (Wright, 1951b), Viséan, United Kingdom. GIUS 5-543 is recognized herein as Lanecrinus? sp. This occurrence questionably expands the Western European range of this genus into the Tournaisian, but in North America, Lanecrinus is known from the Tournaisian through the Moscovian.

GIUS 5-3695/Czatkowice 2 is an isolated pluricolumnal collected in association with the crown described above (Fig. 3I). This pluricolumnal is preserved in a similar manner to Lanecrinus? sp. (GIUS 5-543), but it is not possible to know with certainty whether these two Tournaisian fossils are from the same species. This pluricolumnal fragment has seven nodals preserved with cirri still attached to four. The column is heteromorphic with a construction of N212. The cirri are long and slender.

Measurements: GIUS 5-543: $\mathrm{CrH}, 17.2^{*}$; $\mathrm{ACH}, 3.6^{*}$; $\mathrm{ACW}, 3.2 * ; \mathrm{AH}, 14.8^{*}$; $\mathrm{PbrH}, 2.4,3.6$; PrW, 1.2, 1.2; SbrH, 1.8, 2.2; SbrW, 0.6, 0.8; $\mathrm{CoH}, 7.2 *$.

Range: Mazurowe Doły Formation, Rudawa Group (late Tournaisian); Czatkowice Quarry near Krzeszowice, Dębnik Anticline, Poland.

Individual crinoid ossicles

Fig. 4D-G, 5F, I-V

Material: GIUS 5-3695/Ostrówka 20-54.

Discussion: Many isolated radial plates are present in the washed residues, and the majority of these are interpreted to be eucladids. In addition to those mentioned previously as potential cyathoformes, five distinctive radial plates are illustrated here. GIUS 5-3695/Ostrówka 20 is a small radial plate with very fine granulose sculpturing and a peneplenary radial facet. Low, broad plications project to subjacent basal plates (Fig. 5F). GIUS 5-3695/Ostrówka 21 has similar very fine granulose plate sculpturing, but it has a flat plate surface and a plenary radial facet (Fig. 5I). GIUS 5-3695/Ostrówka 22 has a protruding, declivate, peneplenary radial facet and fine nodose sculpturing (Fig. 5J). GIUS 5-3695/Ostrówka 24 has a protruding, declivate peneplenary radial facet, but plate sculpturing is smooth (Fig. 5K). GIUS 5-3695/Ostrówka 23 is a radial plate with a small facet with a deep pentafascial, plenary radial facet. This radial plate is distinctive because 
425 it has a large spine (relative to the size of the radial plate) projecting abaxially outward $(5 \mathrm{~L}, \mathrm{M})$. 426 Plate sculpturing of GIUS 5-3695/Ostrówka 23 is smooth.

427 Predictably crinoid plates in the washed residues were dominated by brachial plates, 428 pluricolumnals, and columnals. In addition, a few distinctive brachial plates (GIUS 5429 3695/Ostrówka 37-49) and columnals (GIUS 5-3695/Ostrówka 50-54) are noted below. 430 Distinctive brachial plates include GIUS 5-3695/Ostrówka 37, which is a low, weakly cuneate 431 uniserial brachial with a straight articular ridge the full width of the brachial and a very deep 432 adoral groove (Fig. 5O-P). GIUS 5-3695/Ostrówka 38 is a very high, moderately cuneate uniserial brachial with concave lateral sides, trifascial or pentafascial facets, and articular ridges across the entire facet (Fig. 5Q). GIUS 5-3695/Ostrówka 39 is a low, strongly cuneate, uniserial brachial plate. A small spine projects laterally from the higher side of the cuneate brachial (Fig. 5R). GIUS 5-3695/Ostrówka 40 is a small but very high and narrow rectangular uniserial brachial plate with low serrations along the sides of the brachial (Fig. 5N). GIUS 53695/Ostrówka 44 is a large robust axillary first primibrachial plate. All facets have a long, straight articular ridge and are trifascial or pentafascial. This axillary is very similar to the first primibrachials of Hydreinocrinus (e.g., H. goniodactylus (de Koninck \& Wood, 1858) (see Wright, 1951b, pl. 15, fig. 3) (Fig. 5T). GIUS 5-3695/Ostrówka 45 is a uniserial brachial that supported a pinnule. The continuation of the arm projects $\sim 30$ degrees from the axis of the arm, and a distinct, small spine projects laterally below the small pinnule facet (Fig. 5U). GIUS 53695/Ostrówka 46 is a high axillary brachial with the width widening at the facets and the sides concave. It is covered by very fine pustulose sculpturing, and a discontinuous ridge is present along the height in the center of the aboral side of the brachial (Fig. 5S). GIUS 5-3695/Ostrówka 47 is a very high, narrow axillary brachial plate with a convex aboral side (Fig. 5V).

Despite the large number of columnals and pluricolumnals, few have distinctive features. In addition to the columnals described above as Gilbertsocrinus sp. and Platycrinitidae Indeterminate, four additional columnal morphologies are noted here. GIUS 5-3695/Ostrówka 50 has a pentagonal outline, a crenularium of $\sim 33 \%$ of the facet radius, a wide areola, and a circular lumen (Fig. 4D). GIUS 5-3695/Ostrówka 51 is a columnal 2.0 times wider than high with a narrow crenularium, a very wide areola, an elongate lumen that is constricted centrally, and smooth sculpturing on the latus (Fig. 4E). GIUS 5-3695/Ostrówka 52 is a nodal with a similar shape, crenularium, and areola as GIUS 5-3695/Ostrówka 51. It differs by having a circular lumen and distinctive fine nodes on the latus (Fig. 4F). GIUS 5-3695/Ostrówka 53 is a very small, high barrel-shaped columnal with a ridge around the latus at mid-columnal height. Otherwise, the plate sculpturing is smooth (Fig. 4G). This morphology is similar to the flexible crinoid Mespilocrinus (see Wright, 1954a, pl. 67, fig. 23), but this columnal is much shorter than typical for Mespilocrinus. Further, it is a very small size and may be indicative of a juvenile specimen, and this distinctive shape could be a juvenile morphology rather than the adult morphology of Mespilocrinus. 2.5.GIUS 5-3695/Ostrówka 21: RH, 2.6; RmaxW, 3.7; RFW, 3.5. GIUS 5-3695/Ostrówka 22: RH, 4.5; RmaxW, 5.5; RFW, 3.5. GIUS 5-3695/Ostrówka 23: RH, 2.0; RmaxW, 3.2; RFW, 3.2; GIUS 5-3695/Ostrówka 24: RH, 2.9; RmaxW, 3.9; RFW, 3.1. Nonaxillary brachial plates: GIUS 5-3695/Ostrówka 37: BrH, 2.4; BrW, 6.5; GIUS 5-3695/Ostrówka 38: BrH, 8.3; BrW, 3.9; GIUS 5-3695/Ostrówka 39: BrH, 2.9; BrW, 3.9; BrH, 3.4; BrW, 1.5. Axillary brachial plates: 
471 BrW, 1.3. Columnals: GIUS 5-3695/Ostrówka 50: CH, 0.7; CoW, 3.0; GIUS 5-3695/Ostrówka 472 51: CH, 1.8; CW, 2.8; GIUS 5-3695/Ostrówka 52: CH, 1.8; CW, 2.9; GIUS 5-3695/Ostrówka 473 53: $\mathrm{CH}, 1.4 ; \mathrm{CW}, 1.0$.

474 Range: Lechówek Beds (late Viséan); Ostrówka Quarry near Gałęzice, Holy Cross Mountains, 475 Poland.

476

477 Crinoidea Indeterminate A

478 Fig. 3E

479

480

Material: GIUS 5-3695/Ostrówka 9.

481

Discussion: GIUS 5-3695/Ostrówka 9 is a collection of four plates that are an inside view of the basal portion of an aboral cup (Fig. 3E). The four plates are interpreted to be a fused infrabasal circlet and three basal plates. Assuming that the preserved shape of the aboral cup fragment has not been distorted by compaction, this calyx would have had a very gently convex bottom with neither the infrabasal circlet nor most of the basal circlet visible in side view. Viséan dicyclic clades include the diplobathrid camerates, flexibles, and eucladids. This specimen does not appear to conform to the construction of a Viséan diplobathrid in which all adjacent radial plates were separated by intervening plates. The fused infrabasal circlet is a relatively uncommon character for Viséan flexibles and eucladids, and enough morphological information is not preserved to make any further systematic assignment.

491

492

493

494

Range: Lechówek Beds (late Viséan); Ostrówka Quarry near Gałęzice, Holy Cross Mountains, Poland.

Crinoidea Indeterminate B

495

496

Fig. 3K

Material: GIUS 5-3695/Gołonóg 1.

Discussion: A single Serpukhovian crinoid is also present. It is a partially disarticulated crown preserved in a sandstone as iron oxide stained casts and some iron oxide molds. No details of the aboral cup can be deciphered beyond it presumably being relatively small compared to the arms. This crinoid presumably had ten robust, pinnulate arms. Brachials are wider than high, moderately cuneate, aborally convex, and diminish in size distally. Pinnulate, uniserial arms indicate that this crinoid is a eucladid, but no distinguishing characters are preserved that allow an identification other than Crinoidea Indeterminate B.

Range: Gołonóg Sandstone (Serpuhkovian); Dąbrowa Górnicza, Upper Silesian Coal Basin, Poland.

507

508

Class Echinoidea Leske, 1778

$5093 \mathrm{G}$

510

Material: GIUS 5-3695/Ostrówka 56, 57.

512

Discussion: Several isolated echinoid test plates and spines also occur in the Lechówek Beds.

513 These include test plates from a presumed lepidocentrid and spine boss plates and spines from a 514 presumed archaeocidarid echinoid (Fig. 3J). 
515 Measurements: GIUS Ostrówka-56: archaeocidarid spine boss plate (Fig. 3J), diameter: GIUS

516 Ostrówka-57: lepidocentrid ambulacral plate: plate height, 1.5; plate width, 2.1.

517 Range: Lechówek Beds (late Viséan); Ostrówka Quarry near Gałęzice, Holy Cross Mountains,

518 Poland.

519

520

Figures 3-5 around here

521

522

523

524

525

526

527

528

529

530

531

532

533

534

535

536

537

538

539

540

\section{Discussion}

Despite being primarily disarticulated columnal, pluricolumnal, and brachial plates, it is clear that late Tournaisian, late Viséan, and early Serpukhovian crinoid faunas existed in southern Poland. The late Viséan fauna had a high biodiversity and was dominated by cladid crinoids, which is typical for late Viséan crinoid faunas elsewhere (Baumiller, 1994; Ausich et al., 1994; Ausich et al., 2020), and remains of flexible and camerate crinoids are also present. Isolated brachial plates represent only a minority (c.a. 30\%). Selective winnowing may be invoked to explain their scarity. They are primarily from crinoids with uniserial brachial plates and display a high morphological disparity that reflects a high biodiversity. Consistent with the brachials, a high morphological disparity is present in isolated radial plates, columnals, and pluricolumnals. However, without a fauna with complete specimens preserved, it is not possible to identify most of these individual plates beyond higher taxonomic clades.

As described in more detail above, one aboral cup, two fragmentary aboral cups, and three partial crowns (all cladids) were recovered. Knowledge of several key morphological characters are necessary to identify most crinoid genera and species. For cladids, one typically must know the aboral cup shape, the height of the radial plate circlet compared to the aboral cup height, radial facet types, the number and arrangement of posterior interray plates, the number of primibrachials, shape of the brachials, and arm branching pattern.

541

Rather than the column-based taxonomy of previous studies (Głuchowski, 1980a, b, 1981a, b, 1982, 1986, 2001), this study uses crown-based taxonomic names. Among Carboniferous crinoid faunas, crown-based taxa are typically very diverse, whereas column disparity is typically low. Further, columnal morphology can change along a single column. There has been little work to reconcile current column-based taxonomy with crown-based taxonomy on Carboniferous crinoids. However, two very distinctive columnals are assigned to crown-based taxa, including Gilbertsocrinus? sp. and Platycrinitidae Indeterminate. Echinoids were also present in the Lechówek Beds. Because morphological disparity of Mississippian crinoid columns is quite low, this disparity is a poor reflection of the overall crinoid biodiversity. and it is not possible to recognize many crinoid columnals with column-based taxonomic names. Although brachial plate disparity in the fauna is also not a true indication of biodiversity, it should be a much more accurate reflection of biodiversity than isolated columnals. Crinoid arm morphology is a key, commonly species-specific attribute that changes the crinoid filtration fan density, thus defining niches among crinoids (Ausich, 1980; Cole et al., 2019).

554 The descriptions above reveal that diverse Mississippian faunas existed in present-day southern 555 Poland. Most of the crinoidal remains are disarticulated and cannot be identified, but this study demonstrates that continued fieldwork holds promise for discovery of many new specimens that will yield a better understanding of crinoid faunas from the late Tournaisian of the Dębnik anticline region, the late Viséan of the Holy Cross Mountains, and the Serpukhovian of the Upper Silesian Coal Basin. The preservation of partial crowns in all of these settings indicates that depositional conditions were present for excellent crinoid preservation, and the discovery of 
561 additional specimens should be expected. Lanecrinus? sp. is described from the late Tournaisian 562 the Dębnik anticline region, and Crinoidea Indeterminate B is described from the Serpukhovian 563 of the Upper Silesian Coal Basin. Remains of a substantial fauna is described from the late 564 Viséan of the Holy Cross Mountains, including Gilbertsocrinus? sp., Platycrinitidae 565 Indeterminate, Cyathocrinites mammillaris (Phillips, 1836), a flexible crinoid, and partial aboral 566 cups of three eucladids. In addition, radial plates, brachial plates, and columnals described below 567 indicate a much more diverse fauna, as exemplified by the description of five distinct radial 568 plates; eight distinctive brachials; and in addition to Gilbertsocrinus? sp., Platycrinitidae 569 Indeterminate, four distinctive columnal morphologies are described.

Acknowledgements

573

574

We thank Ms. Karolina Paszcza, Mr. Tomasz Borszcz, Mr. Bartosz Czader, and Mr. Mateusz Syncerz, for help during the field works and donating some of specimens to present investigations. We also thank Jeffrey R. Thompson for his advice on identification of the echinoids; and James R. Thomka and an anonymous reviewer, who provided careful reviews that helped us improve this paper. This project was supported by NCN Grant no. 2018/31/B/ST10/00387.

578

579

\section{References}

580

581

582

Ausich, WI. 1980. A model for niche differentiation in Lower Mississippian crinoid communities Journal of Paleontology 54:273-288.

583

584

585

586

587

588

589

Ausich WI, Kammer TW. 2009. Generic concepts in the Platycrinitidae Austin and Austin (Class Crinoidea). Journal of Paleontology 83:694-717.

590

591

592

Ausich WI, Kammer TW, Baumiller TK. 1994. Demise of the Middle Paleozoic crinoid fauna: A single extinction event or rapid faunal turnover? Paleobiology 20:345-361.

593

594

595

Ausich WI, Kammer TW, Rhenberg EC, Wright DF. 2015. Frontiers in Paleontology: Early phylogeny of crinoids within the Pelmatozoan clade. Palaeontology 58:937-952.

Ausich WI, Kammer TW, Mirantsev GV. 2020 (in press). Carboniferous crinoids. 1In: Lucas S. ed. The Carboniferous Time Scale. Geological Society Special Publication Cambridge University Press. 
600

601

602

603

604

605

606

607

608

609

610

611

612

613

614

615

616

617

618

619

620

621

622

623

624

625

626

627

628

629

630

631

632

633

634

635

636
Austin T, Austin T. 1842. XVIII. - Proposed arrangement of the Echinodermata, particularly as regards the Crinoidea, and a subdivision of the Class Adelostella (Echinidae). Annals and Magazine of Natural History, ser. 1, 10, 63:106-113.

Bassler RS. 1938. Pelmatozoa Palaeozoica. In: Quenstedt W. ed. Fossilium catalogus, I. Animalia. Part 83. s'Gravenhage: W. Junk, 194 pp.

Bather FA. 1890. British fossil crinoids. II. The classification of the Inadunata Fistulata (cont'd). Annals and Magazine of Natural History 6: 373-388.

Baumiller TK. 1994. Patterns of dominance and extinction in the record of Paleozoic crinoids. In: David B, Guille A, Féral J-P, Roux M. eds. Echinoderms through time (Echinoderms Dijon). Rotterdam: A.A. Balkema, 93-198.

Bełka Z, Skompski S. 1988. Mechanizm sedymentacji i pozycja facjalna wapienia węglowego w południowo-zachodniej części Gór Świętokrzyskich. Przegląd Geologiczny 8:442-448.

Bełka Z, Skompski S, Sobon-Podgórska J. 1996. Reconstruction of a lost carbonate platform on the shelf of Fennosarmatia: evidence from Viséan polymictic debrites, Holy Cross Mountains, Poland. Geological Society, London, Special Publications 107: 315-329.

Bronn HG, Roemer F (CF). 1851-1856. Lethaea Geognostica oder Abbildung und Beschreibung der für die Gebirgs-Formationen bezeichnendsten Versteinerungen. Dritte stark vermehrte Auflage bearbeitet von H. G. Bronn and F. Roemer, Erster Band. 1. Übersichten, I. Theil. Systematische Übersicht der Fossilien; Schlüssel-Tabellen; Register, von H. G. Bronn. 2. Palaeo-Lethaea. II. Theil. Kohlen-Periode (Silur-, Devon-, Kohlen-, und Zechstein-Formation), von F. Roemer, 788 p., Zweiter Band (1851-52). 3. Meso-Lethaea. III. Theil, Trias-Periode; IV. Theil, Oolithen-Periode; V. Theil, KreidePeriode. Stuttgart: E Schweizerbart, 412 p.

Cole SR. 2017. Phylogeny and morphologic evolution of the Ordovician Camerata (Class Crinoidea, Phylum Echinodermata). Journal of Paleontology 91:815-828.

Cole SR. 2018. Phylogeny and evolutionary history of diplobathrid crinoids (Echinodermata). Palaeontology 62:357-373. 
637 Cole, SR, DF Wright, WI Ausich. 2019. Phylogenetic community paleoecology of one of the

638

639

640

641

642

643

644

645

646

647

648

649

650

651

652

653

654

655

656

657

658

659

660

661

662

663

664

665

666

667

668

669

670

671

672

673 earliest complex crinoid faunas (Brechin Lagerstätte, Ordovician). Palaeogeography, Palaeoclimatology, Palaeoecology 521:82-98.

Czarniecki S. 1959. Anthracoceras discus Frech from the Gołonóg sandstone and the age of this rock. Acta Geologica Polonica 9:433-441.

Doktorowicz-Hrebnicki S. 1935. Szczegółowa mapa geologiczna Polskiego Zagłębia Węglowego 1:25000. Arkusz Grodziec. Warszawa: Państwowy Instytut Geologiczny.

Geinitz HB. 1846. Grundriss der Vesteinerungskunde. Dresden, Lepzig, 345 pp.

Głuchowski E. 1980a. Człony łodyg liliowców w utworach dolnokarbońskich okolic Krakowa. Sprawozdanie z posiedzenia Komitetu Nauk Geologicznych PAN 22:1-16.

Głuchowski E. 1980b. New taxa of Devonian and Carboniferous crinoid stem parts from Poland. Bulletin of the Polish Academy of Science 28:43-49.

Głuchowski E. 1981a. Stratigraphic significance of Paleozoic crinoid columnals from Poland. Zeszyty Naukowe AGH 7:89-110.

Głuchowski E. 1981b. Paleozoic crinoid columnals and pluricolumnals from Poland. Zeszyty Naukowe AGH 7:29-57.

Głuchowski E. 1982. Człony łodyg liliowców karbońskich z otworu wiertniczego B-210 "Julian" GZW. Sprawozdanie z posiedzenia Komitetu Nauk Geologicznych PAN 22: 2-16.

Głuchowski E. 1986. Crinoid ossicles from the Tournaisian of the Gałęzice region, Holy Cross Mountains. Bulletin of the Polish Academy of Science 34:197-207.

Głuchowski E. 2001. Gromada Crinoidea Miller, 1821. In: Pajchlowa M. ed. Budowa Geologiczna Polski. T. III. Atlas skamieniałości przewodnich i charakterystycznych. Młodszy paleozoik. Karbon. Fauna. Państwowy Instytut Geologiczny, 383-396.

Hess H, Ausich WI, Brett CE, Simms MJ. 1999. Fossil Crinoids. Cambridge: Cambridge University Press, 275 pp. 
674 Hollis KA, Ausich WI. 2008. The holdfast of Gilbertsocrinus (Mississippian, Crinoidea).

675

676

677

678

679

680

681

682

683

684

685

686

687

688

689

690

691

692

693

694

695

696

697

698

699

700

701

702

703

704

705

706

707

708

709
Kammer TW, Ausich WI. 2007. Stratigraphical and geographical distribution of Mississippian Crinoidea from Scotland. Earth and Environmental Transactions of the Royal Society of Edinburgh 98:139-150.

Kammer TW, Ausich WI. 1993. Advanced cladid crinoids from the middle Mississippian of the East-Central United States: Intermediate-grade calyces. Journal of Paleontology 67:614639.

Korejwo K, Teller L. 1968a. Stratygrafia karbonu zachodniej części niecki lubelskiej. Acta Geologica Polonica 18:153-177.

Korejwo K, Teller L. 1968b. Stratygrafia karbonu z wierceń Marszowice 1 i Koniusza 1 (niecka miechowska). Acta Geologica Polonica 18:691-706.

Kotas A. 1972. The marine sediments of the Upper Silesian Coal Basin, and their transition into the productive deposits of the Upper Silesian Coal Basin. Prace Instytutu Geologicznego 61:279-328.

Krawczyński W. 2013. Colour pattern of Naticopsisplanispira (Neritimorpha, Gastropoda) shell from Upper Carboniferous of Upper Silesian Coal Basin, southern Poland. Annales Societatis Geologorum Poloniae 83:87-97.

Lane NG. 1963. The Berkeley crinoid collection from Crawsfordsville, Indiana. Journal of Paleontology 3:1001-1008.

Larsen BR, Chan MA, Bereskin SR. 1988. Cyclic stratigraphy of the Upper Member of the Guilmette Formation (Uppermost Givetian, Frasnian), west-central Utah. In: McMilan, N.J., Embry, A.F., Glass, D.J. eds. Devonian of the World. 2. Sedimentation. Canadian Society of Petroleum Geologists Memoir 14:569-579.

Leske NG. 1778. Iacobi Theodori Klein Naturalis disposito Echinodermatum, Edita et aucta a N.G. Leske. Leipzig: G. E. Beer, 278 pp. 
710

711

712

713

714

715

716

717

718

719

720

721

722

723

724

725

726

727

728

729

730

731

732

733

734

735

736

737

738

739

740

741

742

743

744

745

Marynowski L, Salamon MA, Narkiewicz M. 2002. Thermal maturity and depositional environments of organic matter in the post-Variscan succession on the Holy Cross Mountains. Geological Quarterly 46:25-36.

M'Coy F. 1844. A Synopsis of the Characters of the Carboniferous Limestone Fossils of Ireland. Dublin: University Press, 207 pp.

M'Coy F. 1849. On some new Paleozoic Echinodermata. Annals and Magazine of Natural History, ser. 2, 3:244-254.

Meek FB, Worthen AH. 1870. Descriptions of new species and genera of fossils from Paleozoic rocks of the western states. Proceedings of the Academy of Natural Sciences of Philadelphia 22:22-56.

Miller JS. 1821. A natural history of the Crinoidea, or lily-shaped animals; with observations on the genera, Asteria, Euryale, Comatula and Marsupites. Bristol: Bryan \& Co., 150 pp.

Moore RC, Laudon LR. 1943. Evolution and classification of Paleozoic crinoids. Geological Society of America Special Paper 46:1-151.

Moore RC, Jeffords RM. 1968. Classification and nomenclature of fossil crinoids based on studies of dissociated parts of their columns. University of Kansas Paleontological Contribution, Echinodermata 9:1-86.

Paszkowski M. 2009. The Early Triassic karst of Czatkowice 1, southern Poland. Palaeontologia Polonica 65:7-16.

Paszkowski M, Czop M, Gradziński M, Letki S, Lewandowska A, Leśniak T, Motyka J. 2008. A3. Kamieniołom Czatkowice-utwory karbonu dolnego platformy węglanowej bloku Krakowa - historia geologiczna, kontekst paleogeograficzny i strukturalny; warunki hydrogeologiczne; permski kras kopalny. In: Haczewski G. ed. Pierwszy Polski Kongres Geologiczny. Kraków 26-28 czerwca 2008, Przewodnik Sesji Terenowej.

Phillips J. 1836. Illustrations of the geology of Yorkshire, or a description of the strata and organic remains. Pt. 2, The Mountain Limestone districts, 2nd edit. London: John Murray, 203-208. 
747

748

749

750

751

752

753

754

755

756

757

758

759

760

761

762

763

764

765

766

767

768

769

770

771

772

773

774

775

776

777

778

779

780

781
Poty E, Berkowski B, Chevalier E, Hance L. 2007. Sequence stratigraphic and biostratigraphic correlations between the Dinantian deposits of Belgium and Southern Poland (Kraków area). In: Wong TE. ed. Proceedings of the 15th International Congress on the Carboniferous-Permian. Utrecht, 2003. Amsterdam: Royal Netherlands Academy of Arts and Sciences, 97-107.

Riddle SW, Wulff JI, Ausich WI. 1988. Biomechanics and stereomic microstructure of the Gilbertsocrinus tuberosus column. In: Burke RD et al. eds. Echinoderm biology. Proceedings 6th International Echinoderm Conference, Victoria. Rotterdam: A. A. Balkema, 641-648.

Roemer FA. 1870. Geologie von Oberschlesien. Breslau, 587 pp.

Salamon MA. 1998. Górnośląska fauna piaskowców z Gołonoga w NE części Górnośląskiego Zagłębia Węglowego. Unpublished MSc Thesis. Sosnowiec: University of Silesia, 50 pp.

Salamon MA, Gerrienne P, Steemans P, Gorzelak P, Filipiak P, Le Hérissé A, Paris F, CascalesMiñana B, Brachaniec T, Misz-Kennan M, Niedźwiedzki R, Trela W. 2018. Putative Late Ordovician land plants. New Phytologist DOI: doi.org/10.1111/nph.15091.

Salata D. 2013. Heavy minerals as detritus provenance indicators for the Jurassic pre-Callovian palaeokarst infill from the Czatkowice Quarry (Kraków-Wieluń Upland, Poland). Geological Quarterly 57:537-550.

Schmidt WE. 1930. Die fauna des deutschen Unterkarbons. Die Echinodermen des deutschen Unterkarbons. Abhandlungen der Preussischen Geologischen Landesanstalt 122:92 pp.

Thuy B, Kutscher M, Płachno BJ. 2015. A new britlle star from the early Carboniferous of Poland and its imlications on Paleozoic modern-type ophiuroid systematics. Acta Palaeontologica Polonica 60:923-929.

Ubaghs G. 1978a. Skeletal morphology of fossil crinoids. In: Moore RC, Teichert K. eds. Treatise on Invertebrate Paleontology, Echinodermata. Pt. T(2). Boulder and Lawrence: Geological Society of America and University of Kansas Press, T58-T216. 
782

783

784

785

786

787

788

789

790

791

792

793

794

795

796

797

798

799

800

801

802

803

804

805

806

807

808

809

810

811

812

813

814

815

816

817

818
Ubaghs G. 1978b. Camerata. In: Moore RC, Teichert K. eds. Treatise on Invertebrate Paleontology, Echinodermata. Pt. T(2). Boulder and Lawrence: Geological Society of America and University of Kansas Press, T408-T519.

Van Sant JF, Lane GN. 1964. Crawfordsville (Indiana) crinoid studies. University of Kansas Paleontological Contributions. Echinodermata Article 7:136 pp.

Wachsmuth C., Springer F. 1880-1886. Revision of the Palaeocrinoidea. Proceedings of the Academy of Natural Sciences of Philadelphia. Pt. I. The families Ichthyocrinidae and Cyathocrinidae (1880), p. 226-378 (separate repaged p. 1-153). Pt. II. Family Sphaeroidocrinidae, with the sub-families Platycrinidae, Rhodocrinidae, and Actinocrinidae (1881), p. 177-411 (separate repaged, p. 1-237). Pt. III, Sec. 1. Discussion of the classification and relations of the brachiate crinoids, and conclusion of the generic descriptions (1885), p. 225-364 (separate repaged, 1-138). Pt. III, Sec. 2. Discussion of the classification and relations of the brachiate crinoids, and conclusion of the generic descriptions (1886), p. 64-226 (separate repaged to continue with section 1, 139-302).

Wachsmuth C., Springer F. 1897. The North American Crinoidea Camerata. Harvard College Museum of Comparative Zoology, Memoir 20: 1-359, 21: 360-897.

Webster GD. 1974. Crinoid pluricolumnal noditaxis patterns. Journal of Paleontology 48:12831288.

Webster GD, Maples CG. 2008. Cladid crinoid radial facets, brachials, and arm appendages: a terminology solution for studies of lineage, classification, and paleoenvironment. In: Ausich WI., Webster GD. eds. Echinoderm Paleobiology. Bloomington: Indiana University Press, 196-226.

Weigner S. 1938. Fauna piaskowców z Gołonoga. Sprawozdania Państwowego Instytutu Geologicznego 9:3-65.

Wright DF. 2017a. Bayesian estimation of fossil phylogenies and the evolution of early to middle Paleozoic crinoids (Echinodermata). Journal of Paleontology 91:799-814.

Wright DF. 2017b. Phenotypic innovation and adaptive constraints in the evolutionary radiation of Palaeozoic crinoids. Scientific Reports 7:13745.

Peer) reviewing PDF | (2020:10:53626:1:2:NEW 24 Nov 2020) 
819

820 Wright DF, Ausich WI, Cole SR, Peter ME, Rhenberg EC. 2017. Phylogenetic taxonomy and

821 classification of the Crinoidea (Echinodermata). Journal of Paleontology 91:829-846.

822

823

Wright J. 1934. New Scottish and Irish fossil crinoids. Geological Magazine 71:241-268.

824

825

Wright J. 1937. Scottish Carboniferous crinoids. Geological Magazine 74:385-411.

826

827

828

Wright J. 1938a. Some British platycrinidae and descriptions of new species. Geological Magazine 75:266-287.

829

830

Wright J. 1942. New British Carboniferous crinoids. Geological Magazine 79:269-283.

831

832

833

834

835

836

837

838

Wright J. 1950-1960. The British Carboniferous Crinoidea. Palaeontographical Society Monograph, 1(1), 1-24, 1950; 1(2), 25-46, 1951a; 1(3), 47-102, 1951b; 1(4), 103-148, 1952a; 1(5), 149-190, 1954a; 2(1), 191-254, 1955a; 2(2), 255-272, 1955b; 2(3), 273306, 1956b; 2(4), 307-328, 1958; 2(5), 329-347.

Żakowa H. 1956a. Fauna kulmowa z Witkowana Dolnym Śląsku. Biuletyn Instytutu Geologicznego 98:5-76.

839

840

841

842

843

844

Żakowa H. 1962. Warstwy z Lechówka w synklinie łagowskiej. Kwartalnik Geologiczny 6:373-

845

846

847

848

849

850 402.

Żakowa H., Malec J. 1992. Nowe dane o karbonie synkliny kieleckiej (Góry Świętokrzyskie). Kwartalnik Geologiczny 36:305-326.

Zittel K.A. von. 1895. Grundzüge der Palaeontologie (Palaeozoologie). 1st edit. R. Oldenbourg: München, $971 \mathrm{pp}$. 
852

853

854

855

856

857

858

859

860

861

862

863

864

865

866

867

868

869

870

871

872

873

874

875

876

877

878

879

880

881

882

883

884

885

886

887

888

889

890

891

892

893

894

895

Figure Captions:

Figure 01. General map of Poland (A) with enlarged maps of the Holy Cross Mountains (B), Upper Silesian Coal Basin (C), and Dębnik Anticline (D) areas. Modified after Marynowski et al. (2002); Krawczyński (2013); Salata (2013); Salamon et al. (2018).

Figure 02. Stratigraphic columns of investigated sections. A. Dębnik Anticline area. B. Gałęzice area in the Holy Cross Mountains. C. Gołonóg area in Upper Silesian Coal Basin. Modified after Bełka \& Skompski (1988); Paszkowski et al. (2008); Krawczyński (2013).

Figure 03. Early Carboniferous crinoids from Poland, unless noted otherwise, all specimens are from the Ostrówka Quarry, Holy Cross Mountains. Scale bar equals $10 \mathrm{~mm}$. A, B. Cladida Indeterminate A, lateral views of both sides of this incomplete crown; note distinctive morphology of the secundibrachials (GIUS 5-3695/Ostrówka 2).

C, D. Cladida Indeterminate (B) (GIUS 5-3695/Ostrówka 3), lateral view of aboral cup (C); Oral view of of the radial facets of two radial plates.

E. Crinoid Indeterminate A, internal view of the preserved plates from the base of the aboral cup (GUIS 5-3695/Ostrówka 9).

F, G. Cyathocrinites mammilaris (Phillips, 1836) (GIUS 5-3695/Ostrówka 1), (F) Lateral view of aboral cup, note large, radial facets; $(\mathrm{G})$ oral view of aboral cup

H, Lanecrinus? sp., crown, note stout, long pinnules (GIUS 5-543) (from Czatkowice Quarry, Dębnik Anticline).

I. pluricolumnal associated with the crown in $(\mathrm{H})$, this may be a more distal portion of the column of Lanecrinus? sp. (GIUS 5-3695/Czatkowice).

J. Archaeocideroid spine boss plate in a coarse crinoidal rudstone.

K. Crinoidea Indeterminate B from the Dąbrowa Gónicza, upper Silesian Coal Basin (Serpukhovian) (GIUS 5-3695/Gołonóg 1.

Figure 04. Early Carboniferous crinoid columnals from Poland from the Ostrówka Quarry, Holy Cross Mountains. Scale bar equals $1 \mathrm{~mm}$. A-C. Gilbertsocrinus? sp. columnal articular facets, note crenulate perilumen and wide areola on all specimens; (A, B) nodals with epifacet (GIUS 53695/Ostrówka 5; GIUS 5-3695/Ostrówka 6); (C) internodal without epifacet (GIUS 53695/Ostrówka 4).

D. pentagonal columnal with crenularium and relatively wide areola (GUIS 5-3695/Ostrówka 50).

E. oblique view of a columnal with a narrow crenularium and a smooth latus (GIUS 53695/Ostrówka 51).

F. oblique view of a columnal with a narrow crenularium and a nodose latus (GIUS 53695/Ostrówka 52).

G. oblique view of an elongate columnal with a ridge around the columnal at mid height (GIUS 5-3695/Ostrówka 53).

H, I. Platycrinitidae Indeterminate columnal, (H) view or articular facet (GIUS 5-3695/Ostrówka 7), (I) oblique view (GIUS 5-3695/Ostrówka 8). 
896 Figure 05. Early Carboniferous crinoid crown plates from Poland from the Ostrówka Quarry, 897 Holy Cross Mountains. Scale bar equals $1 \mathrm{~mm}$.

898 A-C, E, G, H. Flexibilia Indeterminate, (A) outer surface of radial plate, note notch for petaloid 899 process, (B) inside of radial plate illustrated in (A) (GIUS 5-3695/Ostrówka 12), (C) distal facet 900 of brachial plate (GIUS 5-3695/Ostrówka 14, (E) proximal facet of brachial plate with pateloid 901 process projecting out of the image (GIUS 5-3695/ Ostrówka 13), (G) outer view of axillary 902 plate, $(\mathrm{H})$ distal view with two facets on the axillary plate illustrated in (G) (GIUS 5903 3695/Ostrówka 15).

904 D. radial plate with very fine, granulose plate sculturing and a plenary radial facet (GIUS 5905 3695/Ostrówka14).

906 F. radial plate with very fine, granulose plate sculturing and a peneplenary radial facet (GIUS 5907 3695/Ostrówka 20).

908 I. radial plate (GIUS 5-3695/Ostrówka 21). radial plate with very fine, granulose plate sculturing 909 and a plenary radial facet.

910 J. radial plate with a protruding, declivate radial facet (GIUS 5-3695/Ostrówka 22).

911 K. radial plate (GIUS 5-3695/Ostrówka 24).

912 L, M. radial plate with robust spine (GIUS 5-3695/Ostrówka 23). (L) proximal view with facets 913 to adjacent plates, (distal view illustrating radial facet.

914 N. outer view of a very high brachial plate with serrated sculpturing along its margins (GIUS 5915 3695/Ostrówka 40).

916 O, P. low, weakly cuneate brachial plate, $(\mathrm{O})$ view of facet, $(\mathrm{P})$ outer surface of brachial (GIUS

917 5-3695/Ostrówka 37).

918 Q. high, moderately cuneate brachial plates with concave lateral sides (GIUS 5-3695/Ostrówka $91938)$.

920 R. spinose, cuneate brachial plate (GIUS 5-3695/Ostrówka 39).

921 S. very high axillary brachial plate with strongly concave sides (GIUS 5-3695/Ostrówka 46).

922 T. oblique proximal view of an axillary first primibrachial plate (GIUS 5-3695/Ostrówka 44).

923 U. brachial plate with a pinnular facet (GIUS 5-3695/Ostrówka 45).

924 V. very high axillary brachial plate (GIUS 5-3695/Ostrówka 47). 
Figure 1

General map of Poland (A) with enlarged maps of the Holy Cross Mountains (B), Upper Silesian Coal Basin (C), and Dębnik Anticline (D) area.

Modified after Marynowski et al. (2002); Krawczyński (2013); Salata (2013); Salamon et al. (2018).

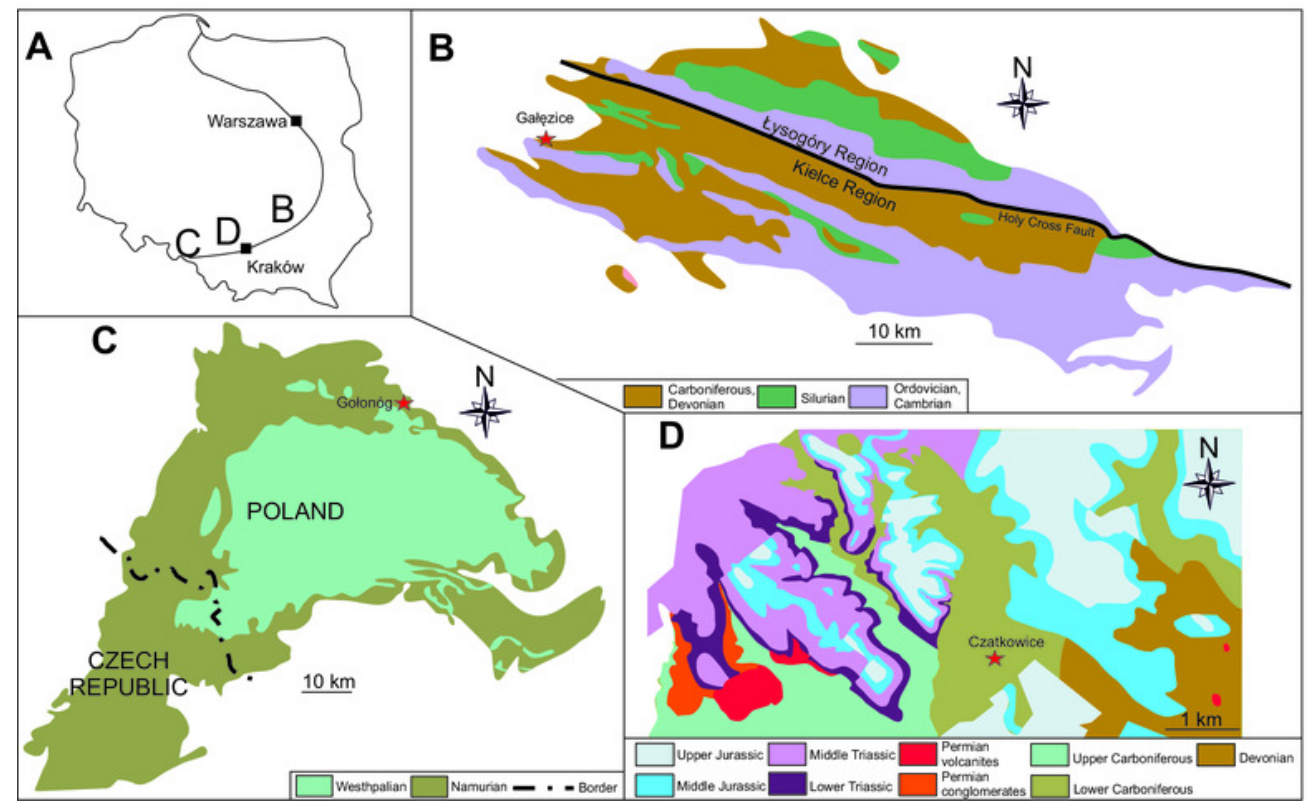


Figure 2

Stratigraphic columns of investigated sections. A. Dębnik Anticline area. B. Gałęzice area in the Holy Cross Mountains. C. Gołonóg area in Upper Silesian Coal Basin.

Modified after Bełka \& Skompski (1988); Paszkowski et al. (2008); Krawczyński (2013). 


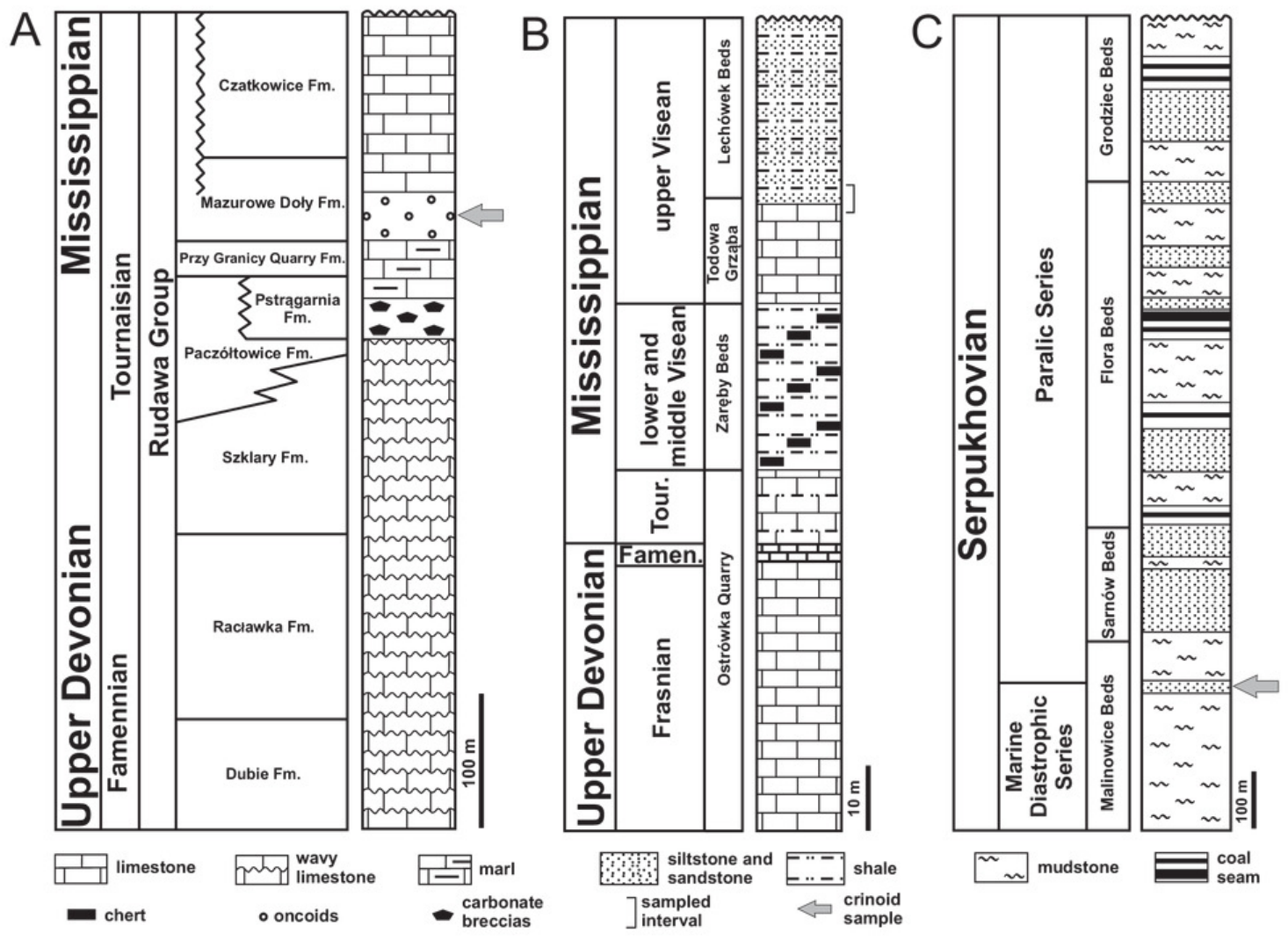

Peer] reviewing PDF | (2020:10:53626:1:2:NEW 24 Nov 2020) 


\section{Figure 3}

Early Carboniferous crinoids from Poland, unless noted otherwise, all specimens are from the Ostrówka Quarry, Holy Cross Mountains. Scale bar equals $10 \mathrm{~mm}$.

A, B. Cladida Indeterminate A, lateral views of both sides of this incomplete crown; note distinctive morphology of the secundibrachials (GIUS 5-3695/Ostrówka 2). C, D. Cladida Indeterminate (B) (GIUS 5-3695/Ostrówka 3), lateral view of aboral cup (C); Oral view of of the radial facets of two radial plates. E. Crinoid Indeterminate A, internal view of the preserved plates from the base of the aboral cup (GUIS 5-3695/Ostrówka 9). F, G. Cyathocrinites mammilaris (Phillips, 1836) (GIUS 5-3695/Ostrówka 1), (F) Lateral view of aboral cup, note large, radial facets; (G) oral view of aboral cup H, Lanecrinus? sp., crown, note stout, long pinnules (GIUS 5-543) (from Czatkowice Quarry, Dębnik Anticline). I. pluricolumnal associated with the crown in $(\mathrm{H})$, this may be a more distal portion of the column of Lanecrinus? sp. (GIUS 5-3695/Czatkowice). J. Archaeocideroid spine boss plate in a coarse crinoidal rudstone. K. Crinoidea Indeterminate B from the Dąbrowa Gónicza, upper Silesian Coal Basin (Serpukhovian) (GIUS 5-3695/Gołonóg 1. 


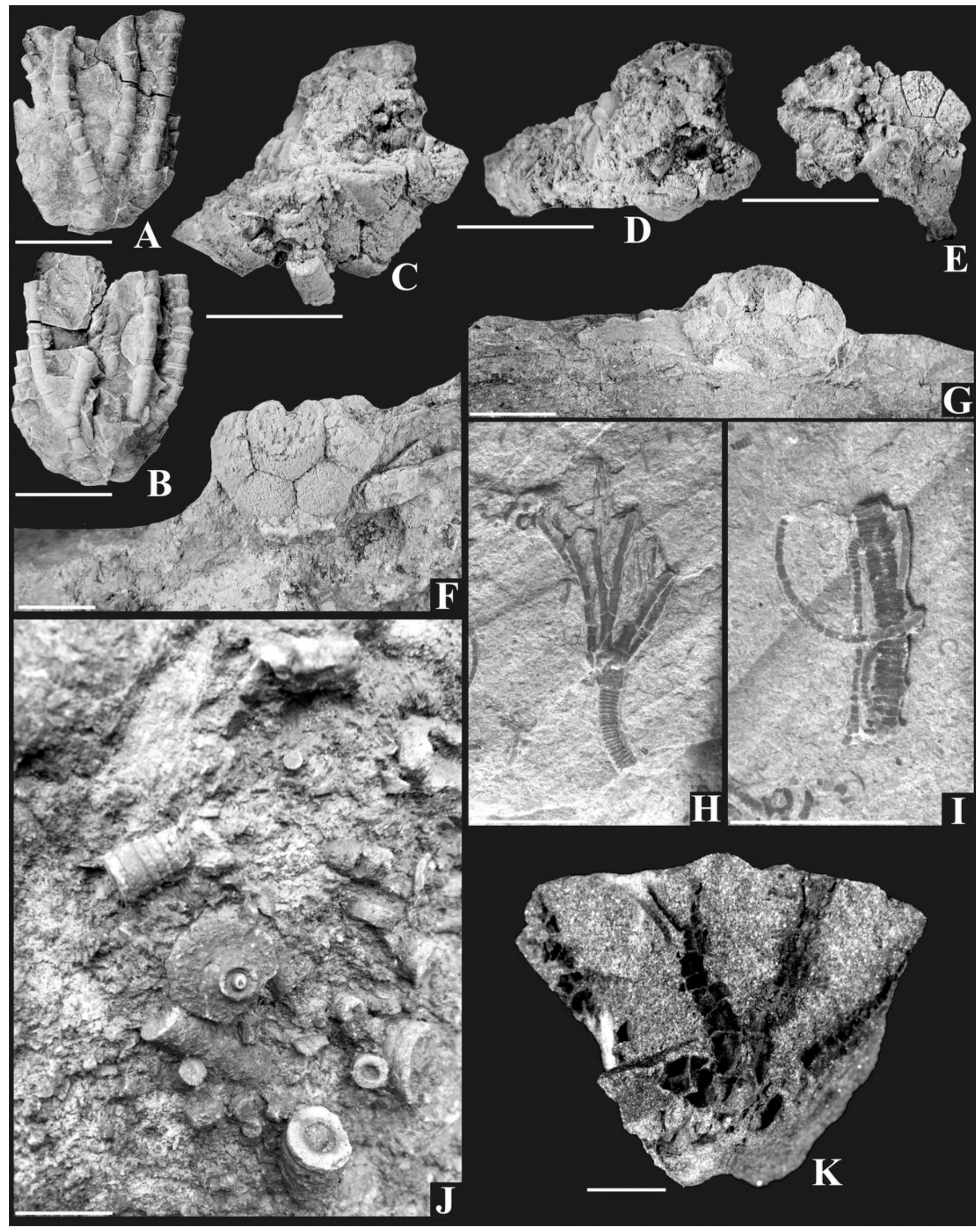




\section{Figure 4}

Early Carboniferous crinoid columnals from Poland from the Ostrówka Quarry, Holy Cross Mountains. Scale bar equals $1 \mathrm{~mm}$.

A-C. Gilbertsocrinus? sp. columnal articular facets, note crenulate perilumen and wide areola on all specimens; (A, B) nodals with epifacet (GIUS 5-3695/Ostrówka 5; GIUS

5-3695/Ostrówka 6); (C) internodal without epifacet (GIUS 5-3695/Ostrówka 4). D. pentagonal columnal with crenularium and relatively wide areola (GUIS 5-3695/Ostrówka 50). E. oblique view of a columnal with a narrow crenularium and a smooth latus (GIUS 5-3695/Ostrówka 51). F. oblique view of a columnal with a narrow crenularium and a nodose latus (GIUS 5-3695/Ostrówka 52). G. oblique view of an elongate columnal with a ridge around the columnal at mid height (GIUS 5-3695/Ostrówka 53). H, I. Platycrinitidae Indeterminate columnal, (H) view or articular facet (GIUS 5-3695/Ostrówka 7), (I) oblique view (GIUS 5-3695/Ostrówka 8). 


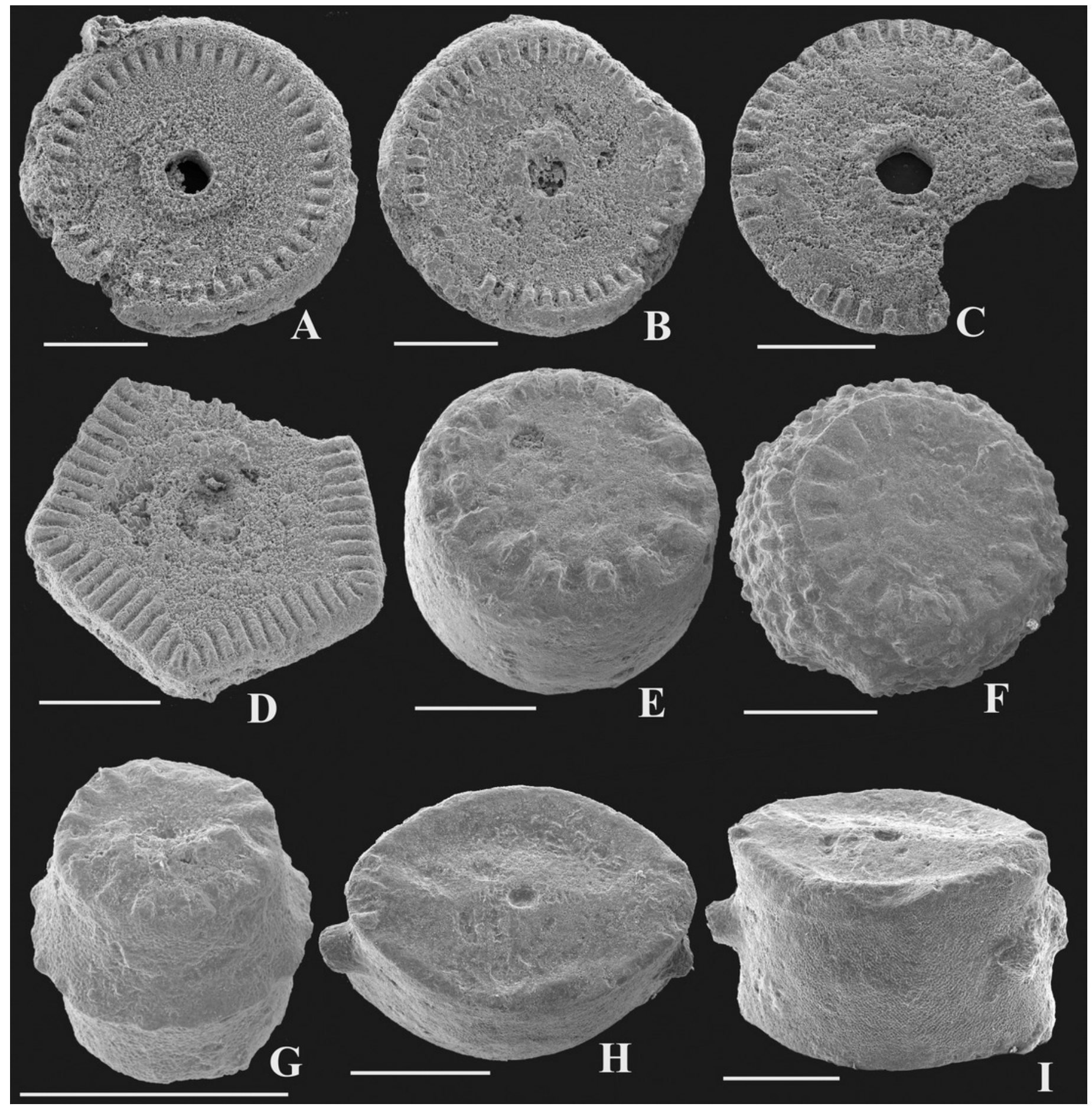




\section{Figure 5}

Early Carboniferous crinoid crown plates from Poland from the Ostrówka Quarry, Holy Cross Mountains. Scale bar equals $1 \mathrm{~mm}$.

A-C, E, G, H. Flexibilia Indeterminate, (A) outer surface of radial plate, note notch for petaloid process, (B) inside of radial plate illustrated in (A) (GIUS 5-3695/Ostrówka 12), (C) distal facet of brachial plate (GIUS 5-3695/Ostrówka 14, (E) proximal facet of brachial plate with pateloid process projecting out of the image (GIUS 5-3695/ Ostrówka 13), (G) outer view of axillary plate, $(H)$ distal view with two facets on the axillary plate illustrated in (G) (GIUS 5-3695/Ostrówka 15). D. radial plate with very fine, granulose plate sculturing and a plenary radial facet (GIUS 5-3695/Ostrówka14). F. radial plate with very fine, granulose plate sculturing and a peneplenary radial facet (GIUS 5-3695/Ostrówka 20). I. radial plate (GIUS 5-3695/Ostrówka 21). radial plate with very fine, granulose plate sculturing and a plenary radial facet. J. radial plate with a protruding, declivate radial facet (GIUS 5-3695/Ostrówka 22). K. radi al plate (GIUS 5-3695/Ostrówka 24). L, M. radial plate with robust spine (GIUS 5-3695/Ostrówka 23). (L) proximal view with facets to adjacent plates, (distal view illustrating radial facet. N. outer view of a very high brachial plate with serrated sculpturing along its margins (GIUS 5-3695/Ostrówka 40). O, P. low, weakly cuneate brachial plate, (0) view of facet, (P) outer surface of brachial (GIUS 5-3695/Ostrówka 37). Q. high, moderately cuneate brachial plates with concave lateral sides (GIUS 5-3695/Ostrówka 38). R. spinose, cuneate brachial plate (GIUS 5-3695/Ostrówka 39). S. very high axillary brachial plate with strongly concave sides (GIUS 5-3695/Ostrówka 46). T. oblique proximal view of an axillary first primibrachial plate (GIUS 5-3695/Ostrówka 44). U. brachial plate with a pinnular facet (GIUS 5-3695/Ostrówka 45). V. very high axillary brachial plate (GIUS 5-3695/Ostrówka 47). 


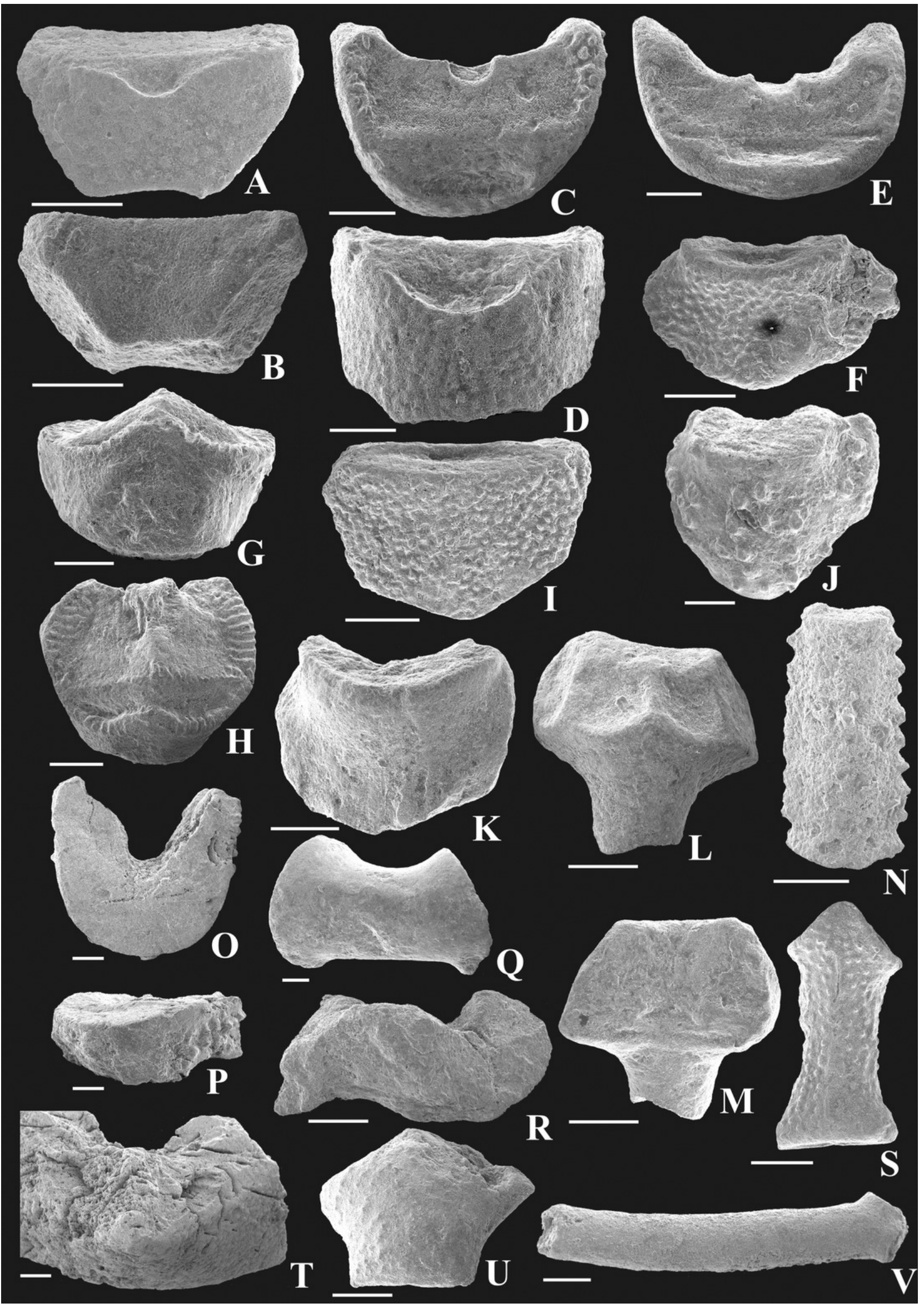

